\title{
35 年前のハワイでの出来事
}

元醸造試験所 小松泰一

\section{ま えがき}

今年も暑い夏がやってきた。この時期になると，私は ハワィでの 35 年前の出来事が想い出される。

30 歳前後の私は, 郷里新潟で頭役として酒造に従事 し, 古くからの「苦労する木に花が咲く」という㕩を信 じて懸命に努力していた。そこへ或る日，「杜氏になる なら 5 月に開かれる大蔵省醸造試験所の酒類講習を受講 するのが早道……という助言を受けた。

この一言が貴重な体験である「ハワイでの酒造り」の 幕開けとなった。

この時期は田植え前で, 農家にとっては猫の手も借り たい農繁期なので決断が鈍っていたが，敢えず入所願い だけは提出しておくことにした。運良く（?）願い叶っ て昭和 14 年, セルの羽織に袴をはき, フィルト草履の 出立ちで試験所の門をくぐることとなった。

そして 2 カ月間に亘る高等講習を無事に修了, これを 記念して目黑の雅敍園で盛大な謝恩会が開催された。

この席上, 山田正一先生から「ハワイに行ってくれな いか」との括しをいただいた。受講したお和蔭で外地へ の招聘を賜わるとは何んと光栄なことかと，心ひそかに 感謝したものである。

\section{ハワイに赴任}

話しはトントン拍子に進み, 出郷したその年の 11 月, ホノルル酒造製水（株）に酒造技師として赴任した。満
33 歳の年である。

ハワィでは, 例によって羽織袴にフィルト草履をつっ かけて闊歩し，道行く人を振り返らせる失態を演じた。 みれば成るほど, 当地では日本女性の晴れ着姿はあって も，男性の着物姿はほとんど見掛けない。

彼の地で一番当惑したのは矢張り会話である。工員の 中には全く日本語の通じないものもいた。そこで仕事に は黒板を利用し，例えば「君は酒袋を洗うように（ユウ 一・ワッシ・バイキ・プリーズ), 米を洗ってくれ(ユウ 一・ワッシ・ライス・プリーズ)」等と書き出して意志 の伝達をはかった。

\section{失敗談あれこれ}

酒母を仕込んで 2 日目，も5フクレがきている。焦っ てしまった。幸いこの件は, 私が内地の酒屋で䊝をもら って甘酒を造った事を思い出し, 早速そのフクレかかっ た酒母を，タンクに入れたままコシキ釜に入れ，品温を 60 度位まで上昇させて $4 \sim 5$ 時間放置した。これを再 び品温 30 度まで下げ，酵母を入れ直す事によってどら にか完全に近い状態に酒母を仕上げることができた。

今思うと, 35 年も前のこの方法は, 最近よく行われ ている高温糖化酒母に似ているよらな父がする。

失敗談はまだある。猌を仕込んで蓋に盛ったが一向に 品温が上らない。そこで室温を上げたり，布を覆せた りまた暖気を入れたりしてみたが依然として効果がな い。シラも進まないのである。

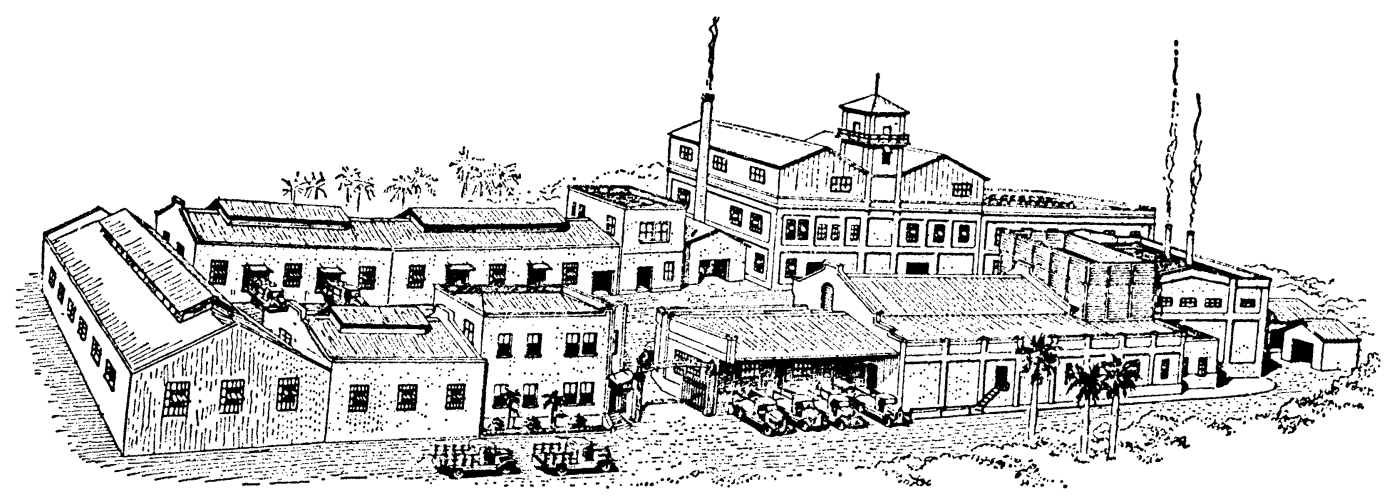

当時のホノルル酒造製氷(株) 
私は思案投げ首で, 精米や洗米係にも途中で手ぬかり がなかったかどらか再確認することにした。最初口をつ ぐんでいた彼等も，私の執拗な質問にポツポツ事の真相 を明かすようになった。それによると, 洗米係が疲労蓄 積で掛け流ししたまま昏々と眠ってしまった由。洗米の 終了時間は午後 10 時頃であるから, 翌朝のコシキ技き 前まで約 8 時間も掛け流ししていたことになる。これで は有効成分が流出してしまう。工員には, 掛け流しは 5 〜 6 分で済むので，美麗になったらすぐに水を止めるよ う前もって厳重に申し渡していたが,どらも襲いかかる 睡魔の敵ではなかったらしい。その楼はトウトウ使用出 来なかった。

\section{四季酮造と税務署員}

四季醸造すまた始めての体験である。1日に 1 本仕込 み 1 本搾る。1本涬引き・沪過・火入れして 1 本嚜詰工 場へ送る。そのため, 途中で何らかの狂いが生ずると全 工程に支障をきたす。造石高は年間約 1 万石であるが, まことに気の抜けない毎日である。

仕込方法は内地と略々同樣であるが, 当地では石数が ギャラン（バレン）に変る。ただし煩珼な税務仕事がな いのが何よりも救いであった。

税務署員は月 1 回, 酒を工場から䭪詰工場へ䔟送する 時に，流量計を見にくるだけである。

それも署員は業者を, 業者は署員を相瓦に信頼しきっ ているので 1 時間足らずで用件が済む。仲々結構な竹国 柄である。

\section{女人採用}

昭和 16 年も想い出深い。当時は大東亜戦争勃発直前 で，当地ではサンバシ作業が非常に景気が良かった。そ こでは労遉も高かったので, 若い者はその方へ走って蔵 では人手不足に陥ったことがある。

その当時, 日本の風習によれぱ, 例之社長夫人であっ ても蔵への立ち入りはご法度の時世である。それを考兄 れば随分思いきった策になるが，人手不足では仕事にな らず, 私は社長淔言して $30 \sim 40$ 歳代の奥さん達 5 6 人を雇っていただいた。しかし, 思惑くとは相違して, 女性採用で随分収檴があった。まず, 今までの陰うつな 空気が一掃され，男子の雇員は髭をそり，身なりるこざ っぱりと整えるようになった。そのう光工場内は隅々ま で見事に掃除されるようになった。

$$
\text { パールハーバー燃ゆ }
$$

生涯最大の衝撃は, 矢張り昭和 16 年 12 月 7 日, 日本 時間の 8 日の出来事である。

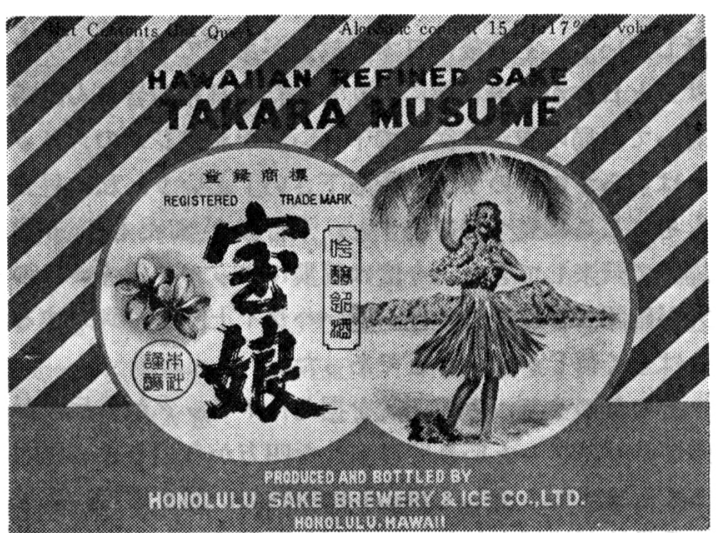

当時の登録商標

晴天の霹震とい拈らか, 世界の楽園といわれたハワイ への日本軍による電光石火の攻撃が，米人，中でも在布 日系人に与光な絶望と悲痛は, とてもはかりしれない。

その日は日曜日で, オピスやビン詰工場は休みに入っ ていた。私は仕込があるので午前 7 時半に出社し、コシ キ場から䅘室, 酒母室, 発酵室等を見巡った。最後に日課 飞従って屋上へ登り,太平洋の景観を味い乍ら遥かなる 祖国の空に過去の出来事を思い浮べていた。すると突然 $5 \sim 6$ 機の飛行機が物凄い速度で頭上を通り過ざていっ た。私はこの時は別に気にもとめなかった。下では 4 , 5 人の女性が粕離しをしている。町の方からは花火のよ らなポンポンといら快音が絶党間なく聞えてきた。そこ で私は奥さん達に「今日は何か行事でああるのでしょう か」と伺ってみた。「日曜ですから技祭りでもやってい るのでしょら」と作業の手を休めない。こうしてしばら く世間話しに花を咲せていると, 表から人が慌てふため いて「大変な事になった。日本軍がポーロハーバーでオ イルタンクや湾内に停泊中の軍艦等を攻撃し大火炎を引 き起している」という。半信半疑で裏山に登ってみると, まさにその通りで，今もな拉無数の飛行機が真珠湾内に 突入している。

このことを仕事中の奥さん達に伝えると「演習でしょ ら」と素っ気ない返事である。「いや，それにしてはタ ンク等の爆発が激しすぎあす」といっても，「それくら いしないと国民は本気になりませんから㸚」と相変らず 相手にしてくれない。

ところが今度は機銃掃射のそぱつ光を喰ったドライバ 一がほうぽらのていで駆け込んできた。奥さん達はここ で始めて驚天動地の大事件を知り, 手持ち品を無造作に まとめて早々に帰宅していった。

一人残された私は, まだ疑念がとけず, 一通りの仕事 を済せてから昼食のため宿舎へ戻った。

ラジオではルーズベルト大統領が, 何にやらしきりに 
話している。その後に日本語放送があって「只今, アメ リカと日本が戦争状態に入りました。日系の皆さんは落 着いて当局の指示に従って下さい。な和ラジオのスイッ チは切らずにそのまま持ち下さい」という。私は昼食 もとこここに表へ飛び出すと, 飛行機がまたも 5,6 機 編隊で飛来してきた。今度は両翼にクッキリと赤い日の 丸が確認できた。日本機が遠いハワイ上空まで到来する とは全く信じがたいことであった。

その日の夕刻, 重機関銃を据えたトラックから兵隊が 飛び降り，アッといら間に当社を四方から遠をきに包囲 してしまった。そして緊迫した雾囲気が漂う中で, 社長 や重役達が逮捕された。

\section{連行さる}

翌朝, 工場長は勿論, 支配人もオピスの方も全く出社 してこない。私は「目米決戦になれば必ず百年戦争にな る」と聞かされていたので, 即刻貴重な米での酒造りを 中止することにした。会社に泊っていた $5 ， 6$ 人を指揮 し, まず精米所にある米を, 白米, 玄米に分類整理し, また仕込中の酒母 16〜18 本並びに添, 踊, 仲のもの全 部を大タンクに合併した。㮃は床にあるもの, 憗蓋に盛 ってあるものも全へてて1カ所に集め, タンク内へ放り込 ませた。これらの仕事は相談する幹部がいないので独壇 でやるしかなかった。

食事の世話人が「あなたも危いからダンタン（町）へ は行かない上らに一。」と助言してくれた。

きけばブラックリストに載っている日系人は, 全員捕 口たとのこと，私もいずれ拘禁される身の上と観念し ていた。ところが 4,5 日経ってもその気配がない。「一 時渡航で身元のハッキリしている自分はもら大丈夫なの だららか」と, 安堵と焦燥の気持が交錯してきた。

ところが一週間目の日曜に, 例によって出社している と, ハワイ大学出身のトガンという人が憲兵 2 人に括巡 り 1 人を帯同してやってきた。そして「ユー小松か」と いら。「そらだ」といらと「きてくれ」といら。そこで 白衣を着用していた私は, 憲兵に「宿舎へ帰り着替えて きたいがどらか?」と質問してみた。「オーライ」の返 事で憲兵とともに宿舎へ直行した。部屋には当時の人気 女優, 三浦光子の写真が掛けておった。それをみて憲兵 は「君の奥さんか，美麗な人だ」と一寸した句をとば した。

服に着替え外に出ると, 車の中には既に一人の日本人 が捕光られていた。そして途中で乗せたるら一人の日本 人とともに，市の薄暗い移民局へと連行された。その時 は, 警戒の目に阻まれ相手の名一つ聞けなかったが，の ちにそのらちの一人 (兽川政男氏) は㐨気の毒にも米本
国飞抑留されて間もなく，不帰の人となってしまわれ た。抑留監禁者の多くは 60〜70 歳の高龄者で, 私など は最も若い部類に属していた。

\section{晴れて 䆏 放}

長い監禁生活から開放され, 第 2 回の交換船に乗るべ くミゾラ・キャンプを出発したのは昭和 18 年 8 月であ った。そして 9 月 1 日, ニューヨーク港でスェーデン汽 船に乗船して, 途中, リオ (ブラジル), モンテビデオ (チリー)，ポートエリザペス（アフリカ南端）を通り,

印度の（ゴアポルトガル領）で日本の帝亜丸に乘り替 之, 11 月 14 日, 奇しくも自分の満 37 歳の誕生日に横浜 埠頭へ第一歩を印すことができた。

\section{再び東京にて}

翌年の 1 月に, 再び山田先生のお世話て醇造試験所に 勤務することになった。

昭和 20 年 4 月 13 日, 東京は夜半から明けがた沉かけ て米車の猛爆を受け, 華の都もあ党なく焦土と化してし まった。この時私は, 醇造試験所の建造物を守るべく火 の子をくぐって消火にあたったが, 所詮は焼き石に水,

当所も激しい焰に吞及込まれてしまった。

現在, 当所の工場での実習生は僅か 3 人であるが, 一 時は 10 名以上も拉って大変賑やかであった。

昨年, 実習関係者に呼びかけ同空会を開催したとこ ろ，50名の参会者が势った。これを記念して当所の庭内 に泰山木 2 本を植樹することができた。

幾藏月, 風雪に耐え齐ばならないこの若木に, ただ幸 多かれと願うものである。

（筆者 51 年 7 月退官）

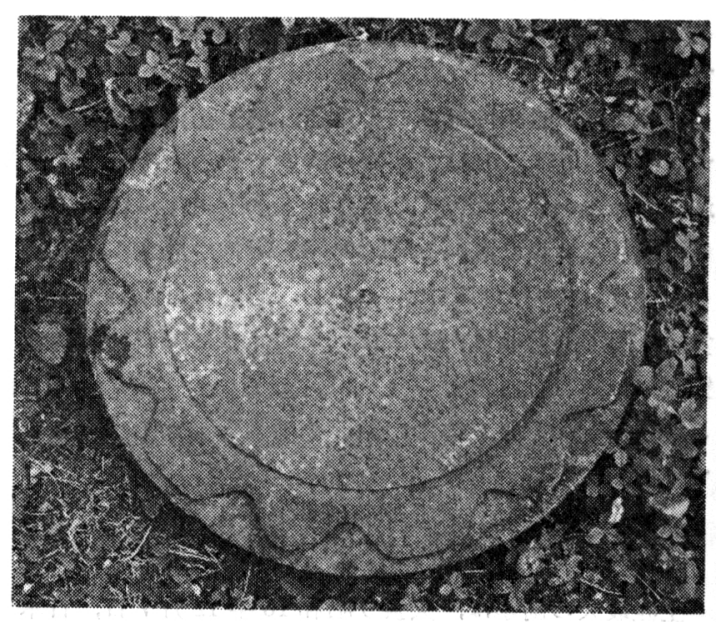

投下された焼夷弾のふた 